\title{
Biological aspects of Lutjanus peru in Bufadero Bay, Michoacán, México: growth, reproduction and condition factors
}

\author{
Aspectos biológicos de Lutjanus peru en Bahía Bufadero, Michoacán, México: \\ crecimiento, reproducción y factores de condición \\ Manuel Gallardo-Cabello ${ }^{1}$, Marcela Sarabia-Méndez ${ }^{1}$, Elaine \\ Espino-Barr ${ }^{2}$ and Vicente Anislado-Tolentino ${ }^{3}$
}

\begin{abstract}
'Departamento de Biología Marina, Instituto de Ciencias del Mar y Limnología, Universidad Nacional Autónoma de México, Apartado Postal 70-305, C.P. 09340, México D.F., México

${ }^{2}$ CRIP-Manzanillo, Instituto Nacional de Pesca, Playa Ventanas s/n, Manzanillo, Colima, 28200, México. elespino@gmail.com

${ }^{3}$ Universidad del Mar-Campus Puerto Ángel, Ciudad Universitaria, Puerto Ángel, San Pedro Pochutla, Oaxaca, C.P. 70902, México
\end{abstract}

\begin{abstract}
Resumen.- Se estudian algunos aspectos biológicos de Lutjanus peru (Pisces: Lutjanidae) recolectado en la Bahía Bufadero, Michoacán, México. El análisis de escamas permitió identificar cuatro anillos de crecimiento, valores similares fueron obtenidos por medio de los estimadores de densidad de Kernel. Los resultados de la ecuación de crecimiento de von Bertalanffy obtenidos por el método lineal simple fueron: $L_{\infty}=81,12 \mathrm{~cm}, W_{\infty}=4.839 \mathrm{~g}, K=0,24$ años $^{-1}$ y $t_{o}=-0,39$ años. Los máximos valores del índice de repleción y del factor de condición ocurren durante los meses de febrero, abril y junio. Los periodos de máxima reproducción ocurren durante los meses de febrero y agosto. Los periodos de reclutamiento al área son de enero a julio para los nacidos en agosto, y de agosto a diciembre para los nacidos en febrero. El tamaño de reclutamiento al arte de pesca es de $18 \mathrm{~cm}$. El índice gonadosomático muestra una relación inversamente proporcional en relación al índice hepatosomático. La longitud corporal de $L$. peru en su primera madurez sexual es de $25,45 \mathrm{~cm}$ y su longevidad es de 12 años. El 65,84\% de la pesca en Bahía Bufadero es de organismos sexualmente inmaduros, por lo que se propone como talla mínima de captura una longitud de $45 \mathrm{~cm}$ (edad 3 años) y un periodo de veda para agosto y septiembre.
\end{abstract}

Palabras clave: Lutjanidae, determinación de la edad, escamas, índice hepatosomático, índice gonadosomático

\begin{abstract}
Some biological aspects of Lutjanus peru (Pisces: Lutjanidae) collected from Bufadero Bay in Michoacán, Mexico, were analyzed. Scale analysis allowed determining four growth rings. Similar data were obtained with an indirect method (Kernel density estimates). Results of von Bertalanffy's growth equation obtained by simple linear method were: $L_{\infty}=81.12 \mathrm{~cm}, W_{\infty}=4,839 \mathrm{~g}, K=0.24$ years $^{-1}$ and $t_{o}=-0.39$ years. The maximum values of the repletion index and condition factor occurred during February, April and June. Spawning peaks occurred between February and August. Recruitment periods in the area were from January to July for those born in August, and August to December for the ones born in February. Recruitment length of the fishing gear is $18 \mathrm{~cm}$ which occurs after age one. The gonadosomatic index is inversely proportional to the hepatosomatic index. Length of first sexual maturity is $25.45 \mathrm{~cm}$. Longevity of L. peru is estimated to be at least 12 years. In Bufadero Bay, $65.84 \%$ of the catch is on sexually immature organisms, therefore we suggest that fishing captures should consider specimens larger than $45 \mathrm{~cm}$ (age 3 years) and a closed season for August and September.
\end{abstract}

Key words: Lutjanidae, age determination, scales, hepatosomatic index, gonadosomatic index

\section{INTRODUCTION}

The Pacific red snapper Lutjanus peru (Nichols \& Murphy, 1922) (Pisces: Lutjanidae) is distributed throughout tropical and subtropical regions, from the Gulf of California to Peru (Allen 1985). This species is demersal inhabiting coastal waters around rocky bottoms and reefs, from 30 to $100 \mathrm{~m}$ in depth (Arellano et al. 2001). During juvenile stages, L. peru lives in estuaries and river mouths forming schools. Once it reaches adulthood it migrates to small coves or cavities to live in solitary or in small groups (Sheaves 1995, Madrid \& Sánchez 1997, Allen \& Robertson 1998, Arellano et al. 2001, Piñón 2003). Its abundance is influenced by sea surface temperature (SST) and decreases during the "El Niño" years (Madrid \& Sánchez 1997). 
This species has an increase activity at dusk (Arellano et al. 2001) due to its carnivorous and opportunistic feeding habits mainly of crabs, prawns, squid, jellyfish and small sized fishes (Rojas et al. 2004a). In tropical areas, where climatic variations are lower than cold and template zones, the spawning and recruitment periods last longer, as in the case of Lutjanus peru in the coast of Manzanillo, two periods yearly including several months each (EspinoBarr 1996).

This species presents an asynchronic reproduction and is a partial spawner with reproductive activity throughout the year (Arellano et al. 2001). Reproductive patterns seem to depend on the size of the population and its distribution along the continental margin (Grimes 1987). Rojas-Herrera (2001) determined the size of first sexual maturation for this species at $29.5 \mathrm{~cm}$ furcal length and a male:female proportion of 1:1.37. Espino-Barr (1996) established February as the month of maximum reproduction, and when the growth ring is formed on scales, as a result of changes in the fish's condition factor, off the coast of Colima, Mexico.

Chiappa-Carrara et al. (2004) observed that recruitment periods do not coincide in time and space for Lutjanus peru and L. guttatus off Guerrero's coast, which can be understood as a phenomenon to lessen interspecific competence and help both species coexist. Espino-Barr et al. (1998) estimated growth parameters using von Bertalanffy's (1938) equation for L. peru along the coast of Colima, Mexico from 1982 to 1997. They documented similar parameters over time, suggesting stability in the population of this species. Fishing assessments of the catch made by Rojo-Vásquez et al. (1999) reported that the selection medium length of $29.1 \mathrm{~cm}$ was obtained with 3 " mesh size gillnet and $33.9 \mathrm{~cm}$ with 3.5 " mesh size gillnet. Cruz-Romero et al. (2000) considered that to protect the existing biomass in Colima, the catch of L. peru should not exceed 150 tonnes. Díaz-Uribe et al. (2004) considered that a fishery regulation is needed on the age or size of first capture of L. peru in the southeast Gulf of California, to avoid overfishing. Ramos-Cruz (2001) suggested a size of minimum capture of $31 \mathrm{~cm}$ total length and a maximum fishing mortality of $F=0.52$ in the coastal zone of Salina Cruz, Mexico.

Total fishery landings of lutjanids in Mexico have increased from 1982 to 2002, ranging between 4,000 (1983) and 11,617 ton (1993) with an average of 7,500 tonnes per year. The state of Michoacán had the sixth highest annual landings of lutjanids in 2005 (305 ton) (Espino-Barr et al. 2006).
It is important to study the population dynamics and life-history characteristics of the Pacific red snapper to be used in assessing stock status and fishery exploitation with the aim of preventing overfishing of this resource. This study has original information on age, growth, longevity, period of reproduction, length of first capture, recruitment, condition factor, gonadosomatic and hepatosomatic indexes of Lutjanus peru along the coast of Michoacán.

\section{Material AND Methods}

Commercial fishery of Bufadero Bay, Michoacán (1804'24”N, 10245'18”W) (Fig. 1) was sampled bimonthly during 5 day periods from August 2005 to June 2006. A total of 1,016 individuals were collected. These were measured for total (TL; $\mathrm{cm}$ ) and standard length (SL; $\mathrm{cm})$, height $(\mathrm{H} ; \mathrm{cm})$ and total $(\mathrm{TW} ; \mathrm{g})$ and eviscerated (EW; g) weight. Liver, gonad and stomach were weighed in situ, preserved in $10 \%$ formalin prepared in sea water. Sex was determined for 347 individuals; the other 668 were immature specimens.

Scales, were collected from behind of pectoral fins of 803 individuals for age analysis. The sample size was calculated with the formula described by Daniel (1991). About 10 scales were taken from an area under the left pectoral fin, below the lateral line (Ruiz-Durá et al. 1970, Holden \& Raitt 1975, Ehrhardt 1981) and stored in dry labeled envelopes. Following the method described by Holden \& Raitt (1975), the scales were washed to clean them and to remove any tissue stuck to them. Four scales were then placed between two microscope slides, sealed with adhesive tape and labeled. Reading of the scales was carried out with the help of a Kodak Ektagraphic transparency projector with a $127 \mathrm{~mm}$ lens (which increases the size of the scale 13.4 times). Scales were measured from the focus to the farthest border as their length and between the longest lateral borders for their width. Growth rings in the scales were counted independently by two different observers. When their results were different, the sample was analyzed again.

Determination of the marginal increment (MI) was carried out according to Lai \& Liu (1979) to determine the date in which the growth ring is formed and to validate the periodicity. The equation is: $\mathrm{MI}=(\mathrm{R}-\mathrm{rn}) /(\mathrm{rn}-\mathrm{rn}-1)$, where $\mathrm{R}=$ scale's radio, $\mathrm{rn}=$ center to last scale's ring distance, $\mathrm{rn}-1=$ center to one before last scale's ring distance.

To compare and validate the scale readings, indirect methods were used: Bhattacharya's (1967) and Kernel density estimates (KDE), to determine components 


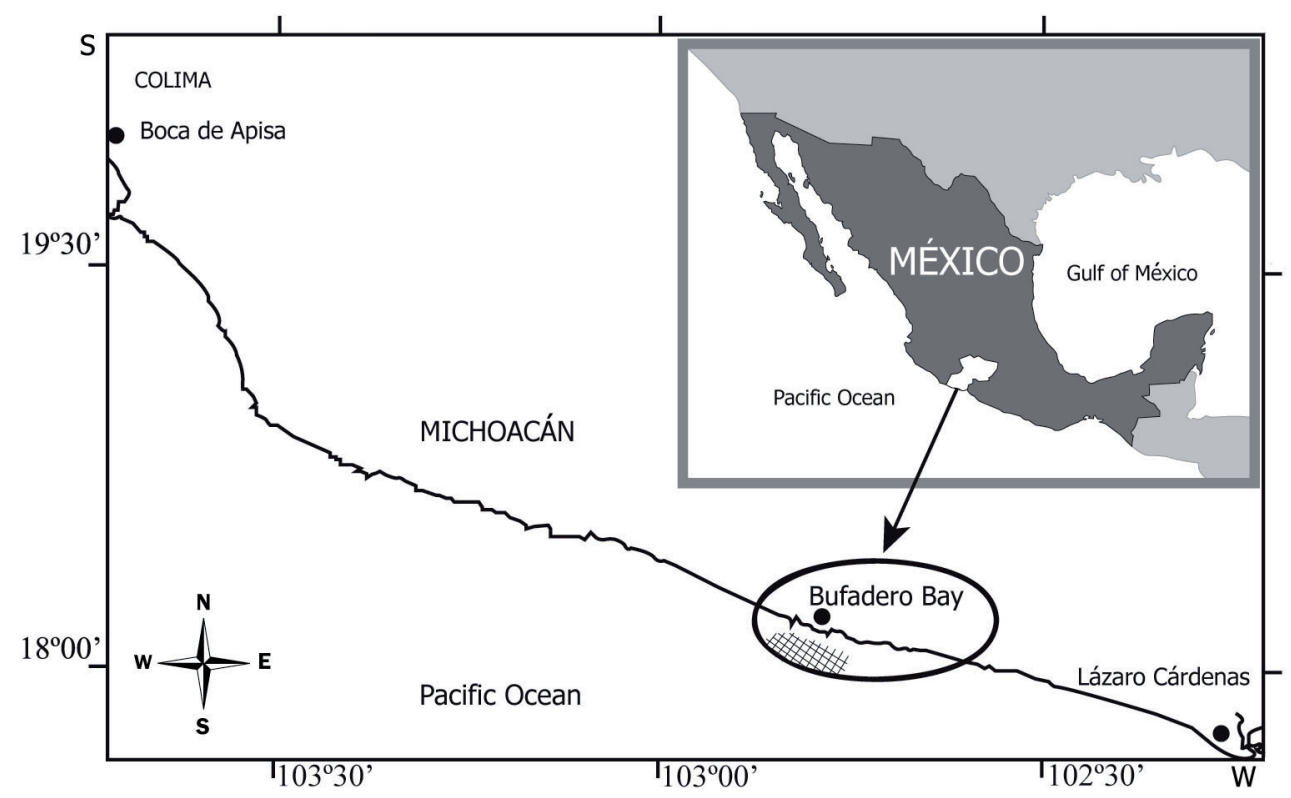

Figure 1. Map of study site / Mapa de la zona de estudio

of the polymodal curve (Salgado-Ugarte 1992, 2002). To specify the suitable bandwidth, Silverman's (1981) smoothed bootstrap method was used with routines of Stata 9.0 proposed by Salgado-Ugarte et al. (2005), which suggests a number of modes in each sampling month with a significant value. Later a KDE was obtained for each sampling month to determine the length classes and their temporal distribution.

The growth constants $L_{\infty}$ (asymptotic length), $K$ (catabolic index) and $t_{\mathrm{o}}$ (organisms age at 0 length) of von Bertalanffy's (vB) equation were obtained with the methods of Ford (1933), Walford (1946), Gulland (1964) and Beverton \& Holt (1959) and two types of regression: simple non linear $\mathrm{vB}$ equation and weighted non-linear $\mathrm{vB}$ equation (Salgado-Ugarte et al. 2005).

Weight-length relationship was calculated with the function $W=a * L^{\mathrm{b}}$ (Mendenhall 1987, Zar 1996), liberalized $\ln$-ln transformation and calculated by least squares. The weight for every age was obtained with the growth data in length and the weight-length function. Weight growth was obtained substituting TL and $L_{\infty}$ for TW and $W_{\infty}$, in vB equation.

Gastric repletion state was classified according to Gallardo-Cabello \& Gual-Frau (1984) as: GRI = number of full stomachs / total number of stomachs. The gonadosomatic index (GSI) was determined with the equation described by Rodríguez-Gutiérrez (1992): GSI= $\mathrm{GW} / \mathrm{TW}^{*} 100$, where: $\mathrm{GW}=\operatorname{gonad}$ weight and $\mathrm{TW}=$ total weight of the individual. The hepatosomatic index (HSI) was calculated according to Rodríguez-Gutiérrez (1992) as HSI $=\mathrm{LW} / \mathrm{TW} * 100$, where: $\mathrm{LW}=$ liver weight and TW $=$ total weight of the individual. Two condition factors were used: eviscerated weight (Clark 1928) and total weight (Fulton 1902). Gonadic maturity index was determined in situ, according to Nikolsky (1963).

Size of first maturity was obtained by the logistic method (Salgado-Ugarte et al. 2005), which fits the sexually mature individuals proportion $(\mathrm{P})$ in relation to TL: $\mathrm{P}=1 /[1+\exp (-\mathrm{r}(\mathrm{TL}-L m))]$, where: $r=$ trend of the curve; $L m=$ mean length of $50 \%$ mature females.

Age limit or longevity $A_{0.95}\left(95 \%\right.$ of $L_{\infty}$ ) was determined mathematically with Taylor's equation $(1958,1960): A_{0.95}$ $=\ln (1-0.95) / K+t_{o}$. And the growth evaluation index, phi prime (Pauly 1991) was used to compare growth curves obtained by different authors: $\Phi^{\prime}=\log _{10} \mathrm{~K}+2 * \log _{10} \mathrm{~L}_{\infty}$, where $\mathrm{K}=$ growth coefficient and $\mathrm{L}_{\infty}=$ asymptotic length.

\section{Results}

Average total length (TL) of Lutjanus peru was 27.13 $\mathrm{cm}$, which corresponds to a maximum body height of $8.41 \mathrm{~cm}$ and $315 \mathrm{~g}$. Length ranged $18.0-61.50 \mathrm{~cm}$, and height of 4.50-18.50 cm. Weight ranged 70-2370 g. The relation between TL and standard length (SL) showed an isometric growth with a slope $b=0.94(P<0.001)$. Also the relationship between TL and height $(\mathrm{H})$ was isometric, with trend $b=0.81$, indicating the relationship between TL 
and height of the organism persists as its age increases $(P$ $<0.001$ ). Total weight (TW) and TL relation has a slope value of $b=2.82$, indicating an isometric relation in which the organism increases its weight proportionally to its length $(P<0.001)$.

The regression scale between length and width indicates an isometric relation with slope $b=1.057(t=3.114, P<$ $0.001)$. There is a direct positive relationship between TL and scale length $b=1.009(t=35.33, P<0.001)$, which makes scales a suitable structure to estimate size of fish (length) for this species. During the sampling months, the ring formation was observed in February $(0.8 \pm 0.54 \mathrm{~mm})$, suggesting that one ring is formed every year. Analysis of scales identified 4 age groups. The percentage of scales showing perfectly defined growth rings was $98 \%$; only $2 \%$ showed regenerated scales. The values obtained with KDE (indirect method) for ages 1 to 4, were: 23.94, 36.94, 44.37 and $57.21 \mathrm{~cm}$ respectively, showing small differences compared with results obtained with scale readings.

Table 1 shows the values of von Bertalanffy's equation constants calculated by three methods: Ford-Walford, Gulland, Beverton \& Holt, Simple non linear vB equation and weighted non linear vB equation: The constants were similar among the methods applied. Nevertheless the nonlinear method provides the best correlation and fits statistically better to the observed data: $L_{\infty}=81.12 \mathrm{~cm}, K=$ $0.24 \mathrm{yr}-1$ and $t_{o}=-0.390$ years $\left(X^{2}=0.99, \mathrm{df}=6, \alpha=0.05\right)$. The longevity of $L$. peru was determined as 12 years old.

Average length values for each age were: $23.19 \mathrm{~cm}$ for age one, $35.64 \mathrm{~cm}$ for age two, $45.41 \mathrm{~cm}$ for age three and $53.09 \mathrm{~cm}$ for age four. Annual instant growth rate in length was $12.45 \mathrm{~cm}$ from ages one to two, $9.78 \mathrm{~cm}$ from two to three and $7.67 \mathrm{~cm}$ from age three to four. Calculated total weight was $142 \mathrm{~g}$ for age one, $474 \mathrm{~g}$ for age two, $943 \mathrm{~g}$ for age three and $1464 \mathrm{~g}$ for age four. The growth curves for observed and calculated values of length and weight for $L$. peru is shown in Fig.2.

Values of von Bertalanffy's growth constants and Pauly's (1987) growth index ( $\phi$ ') for L. peru from the Mexican Pacific coast by different studies, including the present study are shown in Table 2 . The $\phi^{\prime}=3.20$ were within the confidence range for the growth evaluation index.

The increment of condition factor (CF) was observed in February, April and June according to Fulton index, and in April and June according to Clark index. The CF relates to the maximum values of the Gastric repletion index GRI (Table 3). The highest values of the gonadosomatic index
(GSI) were in August and February. With exception of August, values of this index corresponded to the lower monthly values of the hepatosomatic index (HSI) and vice versa (Table 3).

The main spawning period of $L$. peru takes place during August, and a second period during February. Length of first sexual maturity of $L$. peru was $25.45 \mathrm{~cm}$ (TL) equivalent to 1 year old (Fig. 3).

\section{Discussion}

The semi-rectangular ctenoidea scales of this species are considered suitable to determine age and growth as mentioned by Castro (1981), Madrid (1990), Espino-Barr (1996) and Sarabia (2005). The ring used to determine age is formed in February, which coincides with the one observed by Espino-Barr (1996). This ring is formed due to several factors, such as low temperature, changes in the fish condition factor and reproduction activity. It is important to mark that because of these factors, with or in addition to horizontal distribution and bathymetric migrations, also "false rings" are formed on the scales that can be recognized because they are not complete around the scale or because they are not formed by several aggregated lines, with a density that does not allow the light to go by, which one as a dark band (Joseph 1962).

Distance between growth rings diminishes as age increases, which is in agreement with the fact that rate of accumulation of structural components on the scale has an inverse relation over time (Arellano et al. 2001). This way the growth of scale is related to the fish length. Faster growth takes place during the first stages of life before sexual maturity of this fish, after this event the

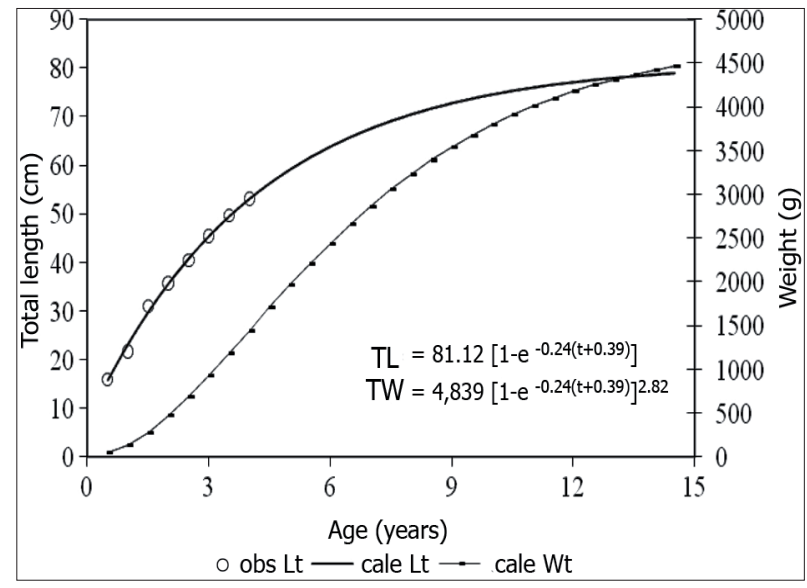

Figure 2. Growth curve in length and weight with von Bertalanffy's equation for $L$. peru / Curva de crecimiento en longitud y peso con la ecuación de von Bertalanffy para L. peru 
Table 1. Growth parameters determined by different methods for Lutjanus peru / Parámetros de crecimiento de Lutjanus peru por diferentes métodos

\begin{tabular}{lccccc}
\hline Parameters & Ford-Walford & Gulland & Beverton \& Holt & $\begin{array}{c}\text { Simple non linear } \\
\text { vB equation }\end{array}$ & $\begin{array}{c}\text { Weighted non linear } \\
\text { vB equation }\end{array}$ \\
\hline$a$ & 9.145 & 9.145 & 4.303 & & \\
$b$ & 0.887 & -0.113 & -0.121 & & \\
$\mathrm{r}^{2}$ & 0.986 & 0.528 & 0.997 & 1.000 & 0.999 \\
Fitted $\mathrm{R}^{2}$ & 0.983 & 0.434 & 0.996 & 0.999 & 0.999 \\
$L_{\infty}$ & 81.24 & 81.24 & 81.24 & 81.12 & 83.07 \\
$K$ & 0.119 & 0.119 & 0.121 & 0.242 & 0.118 \\
$t_{0}$ & & & -0.783 & -0.391 & -0.725
\end{tabular}

Note: $a$ and $b=$ parameters of the lineal fitting to age data; $r^{2}=$ determination index; $L_{\infty} ; K$ and $t_{o}=$ growth parameters

Table 2. Growth parameters of Lutjanus peru, calculated by various authors in different areas of the Mexican Pacific. ( $\mathrm{S}=\mathrm{scales}$; $\mathrm{O=}$ Otoliths; F= Length frequency; SL= Standard length; $T L=$ Total length) / Parámetros de crecimiento de Lutjanus peru obtenidos por varios autores en diferentes áreas del Pacífico mexicano. ( $\mathrm{S}=$ escamas; $\mathrm{O}=$ otolitos; $\mathrm{F}=$ frecuencia de tallas; $\mathrm{SL}=$ longitud estándar; $\mathrm{TL}=$ longitud total)

\begin{tabular}{|c|c|c|c|c|c|c|c|c|}
\hline Study area & Reference & Method & $L_{\infty}(\mathrm{cm})$ & $K(1 /$ year $)$ & $t_{o}$ (year) & Longevity & $\phi$ & Length \\
\hline B.C.S. & Castro (1981) & S & 66.71 & 0.232 & 0.540 & 13 & 3.01 & $\mathrm{TL}$ \\
\hline La Paz, B.C.S. & Rocha \& Muñoz $(1991)^{1}$ & $\mathrm{O}$ & 90.80 & 0.130 & -0.033 & 23 & 3.03 & $\mathrm{TL}$ \\
\hline Barra de Navidad to & González-Ochoa (1997) & $\mathrm{O}$ & 70.50 & 0.090 & 0.500 & 34 & 2.65 & SL \\
\hline \multicolumn{9}{|l|}{ Punta Pérula, Jal. } \\
\hline Jalisco & Espino-Barr et al. (2006) & $\mathrm{F}$ & 121.79 & 0.143 & -0.042 & 21 & 3.33 & TL \\
\hline Colima & Cruz-Romero et al. (1996) & $\mathrm{F}$ & 81.73 & 0.156 & 0.029 & 19 & 2.81 & $\mathrm{TL}$ \\
\hline \multirow[t]{2}{*}{ Colima } & Espino-Barr et al. (1998) & $\mathrm{F}$ & 69.72 & 0.130 & -0.020 & 23 & 2.80 & $\mathrm{TL}$ \\
\hline & & $\mathrm{S}$ & 79.43 & 0.100 & -0.030 & 30 & 2.80 & $\mathrm{TL}$ \\
\hline Colima & Espino-Barr et al. (2006) & $\mathrm{F}$ & 72.42 & 0.130 & 0.006 & 23 & 2.83 & $\mathrm{TL}$ \\
\hline Michoacán & Ruiz-Luna et al. (1985) & $\mathrm{S}$ and $\mathrm{F}$ & 80.50 & 0.190 & 0.756 & 17 & 3.09 & $\mathrm{TL}$ \\
\hline Michoacán & Madrid (1990) & $\mathrm{S}$ & 81.50 & 0.190 & 0.786 & 17 & 3.10 & $\mathrm{TL}$ \\
\hline Michoacán & $\begin{array}{l}\text { Hernández-Montaño et al. } \\
\text { (2002) }\end{array}$ & $\mathrm{F}$ & 95.33 & 0.180 & -0.750 & 16 & 3.21 & $\mathrm{TL}$ \\
\hline Michoacán, Guerrero & Aguilar (1986) & S & 85.02 & 0.110 & -1.570 & 26 & 2.90 & $\mathrm{TL}$ \\
\hline \multicolumn{9}{|l|}{$\&$ Oaxaca } \\
\hline Michoacán & This paper & $\mathrm{S}$ & 81.12 & 0.240 & -0.390 & 12 & 3.20 & $\mathrm{TL}$ \\
\hline Guerrero & Rojas-Herrera (2001) & $\mathrm{O}$ & 92.51 & 0.092 & -1.663 & 31 & 2.90 & $\mathrm{TL}$ \\
\hline Guerrero & Rojas Herrera (2001) & $\mathrm{F}$ & 80.00 & 0.138 & -0.669 & 21 & 2.90 & $\mathrm{TL}$ \\
\hline Guerrero & $\begin{array}{l}\text { Cabrera- Mancilla \& } \\
\text { Gutiérrez-Zavala (2004) }\end{array}$ & $\mathrm{F}$ & 77.00 & 0.084 & -2.532 & 33 & 2.70 & $\mathrm{TL}$ \\
\hline Guerrero & $\begin{array}{l}\text { Santamaría \& Chávez } \\
\text { (1999) }\end{array}$ & $\mathrm{F}$ & 80.80 & 0.140 & 0.230 & 22 & 2.96 & TL \\
\hline Oaxaca & Ramos-Cruz (1996) & $\mathrm{F}$ & 61.80 & 0,153 & -0.303 & 19 & 3.31 & $\mathrm{TL}$ \\
\hline
\end{tabular}

Modified from Espino-Barr et al. (2006)

\footnotetext{
1 Rocha OA \& VM Muñoz. 1991. Relación entre el crecimiento individual y el de los otolitos del huachinango Lutjanus peru (Nichols y Murphy, 1922) en la Bahía de la Paz, B.C.S. p. 28. Resúmenes del II Congreso Nacional de Ictiología. S. Nicolás de los Garza, N.L., México.
} 
growth index of the scale and fish tends to be slow and make themselves asymptotic (Gallardo-Cabello \& GualFrau 1984). Mean length data obtained by scale readings are very similar to those obtained by KDE method, which validates both methods: growth rings identification on hard structures and age groups with polymodal curves analysis.

The relationship between TL and TW in Bufadero Bay, Michoacán, varied monthly mainly because weight was affected by factors such as season, age, food, spawning season, sexual and gonadic maturity (Cushing 1975, Margalef 1989). The asymptotic length value of Lutjanus peru determined in this study was $81.12 \mathrm{~cm}$ and the maximum length observed was $61.50 \mathrm{~cm}$. This was comparable with Chirichigno et al. (1982) reporting 50 $\mathrm{cm}$ mean length in the Central and South oriental Pacific coast. However, other studies have reported maximum TL of $95 \mathrm{~cm}$ (Fischer et al. 1995), and other between 91 and $97 \mathrm{~cm}$ for Colima and Jalisco, respectively (EspinoBarr et al. 2003, 2004). It is important to mention that age determination by von Bertalanffy's equation is an average of lengths and it displays a dispersal range within the growth (Salgado-Ugarte et al. 2005); for this reason organisms of greater longevity may be considered within this dispersion or unusual events of growth, combined with the fact that as populations are closer to the equator the infinite length $\left(L_{\infty}\right)$ tends to be smaller and therefore its growth coefficient $(K)$ higher (Taylor 1958). L. peru populations in areas closer to the equator and living in warmer waters reach smaller average lengths at each age, and populations in northern areas that ones that reach higher fishing yields by the increase of the captured biomass.

The nonlinear parameters of the growth equation were accepted based on additional statistical information such as confidence intervals, $t$ student values and parameters significance, in addition to reduction of deviations by minimum square analysis (Salgado-Ugarte et al. 2005). According to Sparre \& Venema (1995) the nonlinear regression by this analysis is superior to any other procedure from a theoretical and statistical point of view.

Discrepancies found between growth parameters for this species in different areas are due, among other reasons, to the sampling type, method and length used to determine the value of constants, season and latitude where these studies were carried out. Nevertheless, these differences are compensated with the evaluation of the growth index, which shows similar values between populations of the same species or near taxa (Sparre \& Venema 1995).

Biologically, annual trends of the relation between $\mathrm{TL}$ and TW, show that the gain in weight is low before it reaches maturity because the entire energy of the organism is used to increase its length and diminish natural mortality (Cushing 1975). Once it reaches the first sexual maturity, weight gain increases due to reproduction requirements (gonad weight and fat storage), combined with young fish migration towards adult areas. These results have differences in weight according to the quality and amount of food consumed (Allen 1985, Sheaves 1995, Madrid \& Sánchez 1997, Gallardo-Cabello et al. 2007, Espino-Barr et al. 2008). In the present paper the more active feeding periods, represented by values of gastric repletion (GRI) correspond to months of spring and summer, when the availability of food is higher due to a higher temperature and photoperiod. GRI lowers during August due to the reproductive period and increments again during October, the restoration period for the spawning population.

The condition factor that better reflected the quality of the habitat and therefore the food availability was the one

Table 3. Summary of the condition factor (CF), gastric repletion (GRI), gonadosomatic index (GSI) and hepatosomatic index (HSI) of Lutjanus peru / Resumen de los índices del factor de condición (CF), repleción gástrica (GRI), gonadosomático (GSI) y hepatosomático (HSI) de Lutjanus peru

\begin{tabular}{lccccr}
\hline Month & CF Fulton & CF Clark & GRI & GSI & HSI \\
\hline Aug-05 & 1.04 & 0.90 & 0.45 & 6.24 & 3.14 \\
Oct-05 & 1.19 & 0.72 & 0.75 & 0.23 & 0.97 \\
Feb-06 & 1.37 & 0.83 & 0.58 & 1.22 & 0.50 \\
Apr-06 & 1.41 & 1.15 & 0.81 & 0.24 & 0.96 \\
Jun-06 & 1.21 & 1.11 & 1.00 & 0.21 & 0.87 \\
$\mathrm{n}$ & 1,016 & 1,016 & 1,016 & 347 & 347 \\
\hline
\end{tabular}




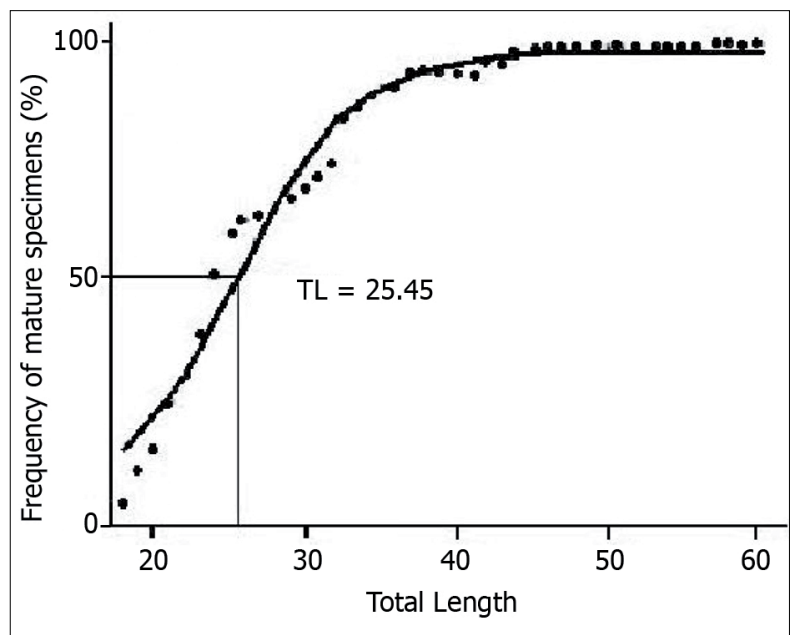

Figure 3. Logistic curve of sexual maturity of L. peru / Curva logística de la madurez sexual de $L$. peru

proposed by Gallardo \& Gual Frau (1984) with the use of the eviscerated weight which allowed eliminating the interference of the gonadic and liver development. These values of CF showed a delay of two months with respect to the gastric repletion index as a reaction of catabolism carried out in nutrient assimilation (Salgado-Ugarte et al. 2005). However, these two parameters keep a close inverse relation (in the case of GSI and GRI) and direct relation in the case of CF and HSI as mentioned by Rocha \& Muñoz (1993) for Lutjanus peru in the Bay of La Paz.

The spawning season estimated in this study (August) agrees with reports of different authors for Colima, Michoacán, Guerrero and Oaxaca, although with exception to Espino-Barr et al. (2006) (Table 4). Pacific red snapper born in August will recruit to the fishing area during January to July; those born in February will be recruited to the area from August to December. These individuals will grow for another two years before they are fully recruited by the fishing gear. At $18 \mathrm{~cm}$ and age group one, organisms of Lutjanus peru are first captured.

Minimum length of first sexual maturity for females in this study was $25.45 \mathrm{~cm}$ TL. Similar values in this study area were found by Ruiz-Luna et al. (1985) and Ruiz (1983), who reported sexually mature red snappers in the state of Michoacán of $28.8 \mathrm{~cm}$. Also Rojas et al. (2004b) calculated first sexual maturity length at $29 \mathrm{~cm} \mathrm{TL}$, but in the state of Guerrero. Higher values were calculated by Santamaría et al. (2003) who reported the beginning of the first sexual maturity at 35-40 cm TL. Cruz-Romero et al. (2000) found in Colima a length at first maturity at 28 and $33 \mathrm{~cm}$ TL for males and females, respectively. Although there are variations in the length at first maturity, L. peru usually reaches it before three years of age (Ruiz 1983,

Table 4. Spawning period of $L$. peru in different states of the Mexican Pacific / Periodo de reproducción de $L$. peru en diferentes estados del Pacífico mexicano

\begin{tabular}{|c|c|c|}
\hline Spawning period & State on the Mexican Pacific & Reference \\
\hline November to April & Baja California Sur & Ochoa et al. $(1991)^{2}$ \\
\hline May to June and November to December & Jalisco & Espino-Barr et al. (2006) \\
\hline January to March and August to September & Colima & Cruz-Romero et al. (1991) \\
\hline March to June and November to December & Colima & Espino-Barr et al. (2006) \\
\hline End of May and middle of November & Michoacán & Madrid (1990) \\
\hline April and September & Michoacán & Ruiz et al. (1982) \\
\hline August & Michoacán & Present paper \\
\hline April and September & Michoacán, Guerrero y Oaxaca & Ruiz (1983) \\
\hline April and September & Michoacán, Guerrero y Oaxaca & Aguilar (1986) \\
\hline March to May and September to December & Guerrero & Rojas-Herrera (2001) \\
\hline April-May and July-September & Guerrero & Rojas-Herrera et al. $(2000)^{3}$ \\
\hline
\end{tabular}

2Ochoa BRS, G Garcia \& R Martínez. 1991. La actividad reproductiva de Lutjanus peru (Perciformes: Lutjanidae) en las costas de San José del Cabo, B.C.S. p.40, Resúmenes del II Congreso Nacional de Ictiología, Sn. Nicolás de las Garzas, N.L., México

${ }^{3}$ Rojas-Herrera AA, A Santamaría \& JF Elorduy. 2000. Desarrollo gonádico y época de desove del huachinango (Lutjanus peru) (Nichols y Murphy, 1922) (Lutjanidae: Perciformes) en la costa de Guerrero, México. Programa y resúmenes del XII Congreso Nacional de Oceanografía, Huatulco, México 
Ruiz-Luna et al. 1985, Cruz-Romero et al. 2000, RojasHerrera 2001), which can be due to the sampling methods, selectivity of fishing gears, or a higher fishing pressure that makes organisms mature at a smaller length.

This species is long-lived because the growth parameter or growth rate $(K)$, which determines the swiftness with which the fish reaches its asymptotic length is low ( $K$ $=0.24 \mathrm{yr}^{-1}$ ) and the maximum age of this species was estimated to be at least 12 years. A high value for this growth rate would indicate a short-lived species that reaches its asymptotic length $\left(L_{\infty}\right)$ in one or two years (Salgado-Ugarte et al. 2005).

The current landing of Lutjanus peru in Bufadero Bay includes $65.84 \%$ immature individuals (669 of 1,016 fish sampled). This trend to harvest immature fish is due a commercial preference for "platillero" (plate size) fish. It is also because these small fish obtain the best price in the tourism sector. Small restaurants (palapa), prefers to sell 6 small fish, equivalent to $0.500 \mathrm{~kg}$ for $\$ 100.00$ pesos each than a single $3 \mathrm{~kg}$ fish for 280 pesos. The "huachinango" (red snapper) fishery constitutes up to $60 \%$ of the fishers' income.

As a measure for protecting this species from overfishing, we suggest a close season during August and September, to give a longer period for spawning, and a first size of capture at $45 \mathrm{~cm}$ of length equivalent to 3 years of age, when most females have reproduced.

\section{LITERATURE CITED}

Aguilar SFA. 1986. Determinación de la edad y estimación de la tasa de crecimiento del huachinango del Pacífico mexicano Lutjanus peru (Nichols y Murphy, 1922) por el método de lectura de escamas. Tesis de Licenciatura de Biología, Facultad de Ciencias, Universidad Nacional Autónoma de México, México, 76 pp.

Allen GR. 1985. FAO Species Catalogue Vol 6. Snappers of the Word. An annotated and illustrated catalogue of Lutjanid species know to date. FAO Fisheries Synopsis 125(6): 1-208.

Allen GR \& RD Robertson. 1998. Peces del Pacífico Oriental Tropical, 327 pp. CONABIO, México.

Arellano MM, A Rojas, F García, B Ceballos \& M Villalejo. 2001. Ciclo reproductivo del pargo lunarejo Lutjanus guttatus (Steindachner, 1986) en las costas de Guerrero, México. Revista de Biología Marina y Oceanografía 36(1): 1-8.

Beverton RJH \& SJ Holt. 1959. A review of the lifespan and mortality rates of fish in nature, and their relation to growth and other physiological characteristics. In: Wolstenhome GEW \& M O'Connor (eds). Ciba Foundation Colloquia on Ageing: the lifespan of animals, 5: 142-180. J \& A Churchill, London.

Bhattacharya CG. 1967. A simple method of resolution of a distribution into Gaussian components. Biometrics 23: 115-135.

Cabrera-Mancilla E \& RM Gutiérrez-Zavala. 2004. Análisis de la pesquería del huachinango Lutjanus peru en el litoral de Guerrero, México, 50 pp. Informe de Investigación, Documento Interno SAGARPA/INP, México.

Castro CF. 1981. El huachinango en la bahía de San José, B.C.S., determinación de edad y crecimiento (Lutjanus peru). Universidad Autónoma de Sinaloa. Revista Ciencias del Mar 1: 4-8.

Chiappa-Carrara X, A Rojas-Herrera \& M Mascaro. 2004. Coexistencia de Lutjanus peru y Lutjanus guttatus (Pisces: Lutjanidae) en la costa de Guerrero, México: relación con la variación temporal en el reclutamiento. Revista de Biología Tropical 52(1): 177-185.

Chirichigno N, W Fischer \& CW Nauen. 1982. INFOPESCA. Catálogo de especies marinas de interés económico actual o potencial para América Latina. Parte 2. Pacífico Centro y Suroriental, SIC/82/2: 1-588. FAO/PNUD, Roma.

Clark F. 1928. The weigth-length relationship of the Californian sardine (Sardina coerulea) at San Pedro. California Department of Fish \& Game, Fish Bulletin 12: 22-44.

Cruz-Romero M, E Espino-Barr, J Mimbela, A Garcia-Boa, LF Obregón \& E Girón. 1991. Biología reproductiva en tres especies del género Lutjanus en la costa de Colima, México, 118 pp. Informe Final, Clave CONACYT: P220CCoR892739, México.

Cruz-Romero M, EA Chávez, E Espino-Barr \& A GarciaBoa. 1996. Assessment of a snapper complex (Lutjanus spp.) of the Eastern Tropical Pacific. In: Arreguín-Sánchez F, JL Munro, MC Balgos \& D Pauly (eds). Biology, fisheries and culture of tropical groupers and snappers. ICLARM Conference Proceedings 48: 324-330.

Cruz-Romero M, E Espino-Barr, P Del Monte-Luna, A Garcia-Boa, A Ayala-Cortés, JJ González-Ruíz \& S Sánchez-González. 2000. Huachinango del Pacífico. In: Cisneros-Mata MA \& L Beléndez (eds). Sustentabilidad y pesca responsable en México. Evaluación y manejo 19992000, pp. 297-326. INP-SEMARNAP, México.

Cushing DH. 1975. Ecología marina y pesquerías, 237 pp. Acribia, Zaragoza.

Daniel WW. 1991. Bioestadística. Base para el análisis de las ciencias de la salud, 667 pp. Noriega-Limusa, México. 
Díaz-Uribe G, E Chávez \& JF Elorduy. 2004. Assessment of the Pacific red snapper (Lutjanus peru) fishery in the southwestern Gulf of California. Ciencias Marinas 30(4): 561-574.

Ehrhardt N. 1981. Curso sobre métodos en dinámica de poblaciones. 1a.Parte. Estimación de parámetros poblacionales, $150 \mathrm{pp}$. INP/SEPESCA, México.

Espino-Barr E. 1996. Edad y crecimiento del huachinango Lutjanus peru (Nichols y Murphy, 1922), en las costas de Colima, México. Tesis de Maestría, Facultad de Ciencias, Universidad Nacional Autónoma de México, México, 73 pp.

Espino-Barr E, M Cruz-Romero \& A Garcia-Boa. 1998. Tendencia de la talla del huachinango Lutjanus peru en Colima, México, de noviembre de 1982 a diciembre de 1997. Ciencia Pesquera 14: 147-150.

Espino-Barr E, M Cruz-Romero \& A Garcia-Boa. 2003. Peces marinos con valor comercial de la costa de Colima, México, 106 pp. CONABIO, INP, CRIP-Manzanillo, México.

Espino-Barr E, EG Cabral-Solís, A Garcia-Boa \& M PuenteGómez. 2004. Especies marinas con valor comercial de la costa de Jalisco, México, 145 pp. SAGARPA, INP, México.

Espino-Barr E, D Hernández-Montaño, E CabreraMancilla, RM Gutiérrez-Zavala, HA Gil-López, EG Cabral-Solís, A García-Boa, C Meléndez, M PuenteGómez \& C Romero-Acosta. 2006. Huachinango del Pacífico Sur. In: Arreguín-Sánchez F, L Beléndez-Moreno, I Meléndez-Gómez, R Solana-Sansores \& C RancelDávalos (eds). Sustentabilidad y pesca responsable en México. Evaluación y manejo, pp. 101-129. INPSAGARPA, México.

Espino-Barr E, M Gallardo-Cabello, EG Cabral-Solís, A Garcia-Boa \& M Puente-Gómez. 2008. Growth of the Pacific jack Caranx caninus (Pisces: Carangidae) from the coast of Colima, México. Revista de Biología Tropical 56(1): 171-179.

Fischer W, F Krupp, W Schneider, C Sommer, KE Carpenter \& VH Niem. 1995. Guía FAO para la identificación de especies para los fines de la pesca. Pacífico Centro Oriental, 3: 1201-1813. FAO, Roma.

Ford E. 1933. An account of the herring investigations conducted at Plymouth during the years from 1924 to 1933. Journal of the Marine Biological Association of the United Kingdom 19: 305-384.

Fulton TW. 1902. Rates of growth of sea-fishes. Scientific Investigations, Fishery Division of Scotland Report 20: $1-22$.

Gallardo-Cabello M \& A Gual-Frau. 1984. Consideraciones bioecológicas durante el crecimiento de Phycis blennoides
(Brünnich, 1768) en el Mediterráneo Occidental (Pisces: Gadidae). Anales del Instituto de Ciencias del Mar y Limnología, UNAM 11(1): 225-238.

Gallardo-Cabello M, E Espino-Barr, A Garcia-Boa, EG Cabral-Solís \& M Puente-Gómez. 2007. Study of the growth of the green jack Caranx caballus Günther 1868, in the coast of Colima, México. Journal of Fisheries and Aquatic Science 2(2): 131-139.

Grimes CA. 1987. Reproductive biology of the Lutjanidae. In: Polovina JJ \& S Ralston (eds). Tropical snapper and grouper: Biology and fisheries management, pp. 239-294. Westview Press, Boulder.

González-Ochoa OA. 1997. Edad y crecimiento de Lutjanus peru en la costa Sur de Jalisco. Tesis de Licenciatura, Universidad de Guadalajara, Guadalajara, $80 \mathrm{pp}$.

Gulland JA. 1964. Manual of methods of fish population analysis. FAO Fisheries Technical Paper 40: 1-60.

Hernández-Montaño D, C Meléndez \& C Romero. 2002. Evaluación de recursos pesqueros (escama) en la costa de Michoacán, 50 pp. Informe Final Interno, SAGARPAInstituto Nacional de la Pesca, CRIP Pátzcuaro, México.

Holden MJ \& DFS Raitt. 1975. Manual de Ciencia Pesquera. Parte 2.- Métodos para investigar los recursos y su aplicación. ONU/FAO Documento Técnico de Pesca 115, Rev. 1: 1-255.

Joseph DC. 1962. Growth characteristics of two Southern California surffishes, the California corbina and Spotfin Croaker, Family Sciaenidae. The Resources Agency of California. Dep. of Fish and Game. Fish Bulletin 119: 1-54.

Lai HL \& H Liu. 1979. Age and growth of Lutjanus sanguineus in the Arafura Sea and North of West shelf. Acta Oceanographica Taiwanica 10: 164-175.

Madrid VJ. 1990. Ecología de algunas especies de peces de importancia comercial. Tesis de maestría, Facultad de Ciencias, Universidad Nacional Autónoma de México, México, 179 pp.

Madrid VJ \& P Sánchez. 1997. Patterns in marine fish communities as shown by artisanal fisheries data on the shelf off the Nexpa River, Michoacán México. Fisheries Research 33: 149-158.

Margalef R. 1989. Ecología, 951 pp. Omega, Barcelona.

Mendenhall W. 1987. Introduction to probability and statistics, 884 pp. PWS-Kent Publishing Company, Boston.

Nikolsky GV. 1963. The ecology of fishes, $351 \mathrm{pp}$. Academic Press, London.

Pauly D. 1987. Review of the ELEFAN system for the analysis of length frequency data in fish and aquatic invertebrates. ICLARM, Contribution 232: 7-34.

Pauly D. 1991. Growth performance in fishes: Rigorous 
description of patterns as a basis for understanding causal mechanisms. Aquabyte 4(3): 3-6.

Piñón GA. 2003. Contribución al conocimiento de la biología de las especies Hoplopagrus guentherii, Lutjanus argentiventris, Lutjanus colorado y Lutjanus guttatus de la Bahía de Mazatlán y Santa María la Reforma. Tesis de Maestría, Instituto de Ciencias del Mar y Limnología, Universidad Nacional Autónoma de México, México, 106 pp.

Ramos-Cruz S. 1996. Evaluación de la pesquería de lutjánidos (pargos y huachinango) en el área costera de Salina Cruz, Oaxaca, México. Boletín Informativo, CRIP-Salina Cruz: $1-13$.

Ramos-Cruz S. 2001. Evaluación de la pesquería de huachinango Lutjanus peru en la zona costera de Salina Cruz, Oaxaca, México, durante 1995. Ciencia Pesquera 14: 151-157.

Rocha OA \& VM Muñoz. 1993. Validación del uso de otolitos para determinar la edad del huachinango del Pacífico Lutjanus peru (Perciformes: Lutjanidae), en la Bahía de La Paz y aguas adyacentes, BCS, México. Ciencias Marinas 19(3): 321-331.

Rodríguez-Gutiérrez M. 1992. Técnicas de evaluación cuantitativa de la madurez gonádica en peces, 79 pp. AGT, México.

Rojas MJ, E Maravilla \& F Chicas. 2004a. Hábitos alimentarios del pargo de la mancha, Lutjanus guttatus (Pisces: Lutjanidae) en Los Cóbanos y Puerto La Libertad, El Salvador. Revista de Biología Tropical 52(1): 23-30.

Rojas AP, C Gutiérrez \& V Puentes. 2004b. Aspectos de la biología y dinámica poblacional del pargo coliamarillo Lutjanus argentiventris en el Parque Nacional Gorgona, Colombia. Investigaciones Marinas 32(2): 23-36.

Rojas-Herrera AA. 2001. Aspectos de dinámica de poblaciones del huachinango Lutjanus peru (Nichols y Murphy, 1922) y del flamenco Lutjanus guttatus (Steindachner, 1869) (Pisces: Lutjanidae) del litoral de Guerrero, México. Tesis de Doctorado, Facultad de Medicina, Veterinaria y Zootecnia, Universidad de Colima, México, 194 pp.

Rojo-Vásquez JA, F Arreguín-Sánchez, E GodínezDomínguez \& M Ramírez-Rodríguez. 1999. Selectividad de redes de enmalle para el pargo lunarejo (Lutjanus guttatus) y el pargo alazán (Lutjanus argentiventris) en Bahía de Navidad, Jalisco, México. Ciencias Marinas 25(1):145-152.

Ruiz SH. 1983. Reproducción del huachinango Lutjanus peru (Nichols y Murphy, 1922) (Pisces Lutjanidae) del Pacífico Sur de México. Tesis Profesional, Universidad Nacional Federico Villareal, Lima, 72 pp.
Ruiz SH, A Osegueda, M Guzmán \& S Coronel. 1982. Ciclo reproductor del huachinango Lutjanus peru (Nichols y Murphy, 1922) (Pisces Lutjanidae) del Pacífico Sur de México, 15 pp. Instituto de Ciencias del Mar y Limnología, Universidad Nacional Autónoma de México, México.

Ruiz-Durá MF, Y Orijel-Arenas \& G Rodríguez-Hernández. 1970. Líneas de crecimiento en escamas de algunos peces de México. Instituto Nacional de Investigaciones Biológico Pesqueras. Serie Investigación Pesquera, Estudio 2: 1-97.

Ruiz-Luna A, E Girón, J Madrid \& A González. 1985. Determinación de edad, crecimiento y algunas constantes biológicas del huachinango del Pacífico Lutjanus peru (Nichols y Murphy, 1922). Memorias del VII Congreso Nacional de Zoología, Morelia, México, pp. 188-201.

Salgado-Ugarte IH. 1992. El análisis exploratorio de datos biológicos. Fundamentos y aplicaciones, 243 pp. Escuela Nacional de Estudios Profesionales Zaragoza, UNAM and Marc ediciones, México.

Salgado-Ugarte IH. 2002. Suavización no paramétrica para el análisis de datos, 139 pp. Escuela Nacional de Estudios Profesionales Zaragoza, UNAM, México.

Salgado-Ugarte IH, JL Gómez-Márquez \& B PeñaMendoza. 2005. Métodos actualizados para el análisis de datos Biológicos-Pesqueros, 240 pp. Escuela Nacional de Estudios Profesionales Zaragoza, UNAM, México.

Santamaría MA \& EA Chávez. 1999. Evaluación de la pesquería de Lutjanus peru (Pisces: Lutjanidae) de Guerrero, México. Revista de Biología Tropical 47(3): 571-580.

Santamaría MA, J Elorduy \& AA Rojas. 2003. Hábitos alimentarios de Lutjanus peru (Pisces: Lutjanidae) en las costas de Guerrero, México. Revista de Biología Tropical 51(2): 1-17.

Sarabia MM. 2005. Determinación de la edad y crecimiento del pargo flamenco Lutjanus guttatus (Steindachner, 1869) (Pisces: Lutjanidae), mediante el análisis de escamas en Bahía Bufadero: Michoacán, México. Tesis de Licenciatura, Facultad de Ciencias, Universidad Nacional Autónoma de México, México, 54 pp.

Sheaves M. 1995. Large Lutjanid and Serranid fishes in tropical estuaries: Are they adults or juveniles? Marine Ecology Progress Series 129: 31-40.

Silverman BW. 1981. Using kernel density estimates to investigate multimodality. Journal of the Royal Statistical Society B 43: 97-99.

Sparre P \& SC Venema. 1995. Introducción a la evaluación de recursos pesqueros tropicales. Parte 1 - Manual. FAO Documento Técnico de Pesca 306(1), Rev 1: 1-420. 
Taylor CC. 1958. Cod growth and temperature. Journal du Conseil 23(3): 366-370.

Taylor CC. 1960. Temperature, growth and mortality -the Pacific cockle. Journal du Conseil 26(1): 117-124.

Von Bertalanffy L. 1938. A quantitative theory of organic growth (inquiries on growth laws II). Human Biology 10(2): 181-213.
Walford LA. 1946. A new graphic method of describing the growth of animals. The Biological Bulletin 90(2): 141-147.

Zar JH. 1996. Biostatistical analysis, 662 pp. Prentice Hall, Upper Saddle River.

Recibido el 26 de agosto de 2009 y aceptado el 4 de marzo de 2010 